\title{
Perceptive evaluation of Korean native speakers on the polysemic sentence final ending produced by Chinese Korean learners
}

\author{
Youngsook Yune* \\ College of General Education, Kyungnam University, Changwon, Korea
}

\begin{abstract}
The aim of this study is to investigate the perceptive aspects of the polysemic sentence final ending "-(eu)lgeol" produced by Chinese Korean learners. "-(Eu)lgeol" has two different meanings, that is, a guess and a regret, and these different meanings are expressed by the different prosodic features of the last syllable of "-(eu)lgeol". To examine how Korean native speakers perceive "-(eu)lgeol" sentences produced by Chinese Korean learners and the most saliant prosodic variable for the semantic discrimination of "-(eu)lgeol" at the perceptive level, we performed a perceptual experiment. The analysed material constituted four Korean sentences containing "-(eu)lgeol” in which two sentences expressed guesses and the other two expressed regret. Twenty-five Korean native speakers participated in the perceptual experiment. Participants were asked to mark whether "-(eu)lgeol" sentences they listened to were (1) definitely regrets, (2) probably regrets, (3) ambiguous, (4) probably guesses, or (5) definitely guesses based on the prosodic features of the last syllable of "-(eu)lgeol". The analysed prosodic variables were sentence boundary tones, slopes of boundary tones, pitch difference between sentence-final and penultimate syllables, and pitch levels of boundary tones. The results show that all the analysed prosodic variables are significantly correlated with the semantic discrimination of "-(eu)lgeol" and among these prosodic variables, the most salient role in the semantic discrimination of "-(eu)lgeol" is pitch difference between sentence-final syllable and penultimate syllable.
\end{abstract}

Keywords: polysemic sentence final ending, perceptive analysis, sentence boundary tone, pitch difference, L2 intonation

\section{1. 서론}

한국어에는 하나의 형태로 두 개 이상의 서로 다른 의미를 전 달하는 다양한 동형다의 종결어미가 존재한다. 대부분의 경우 종결어미가 지니는 두 개의 서로 다른 의미는 오름과 내림이라 는 서로 다른 형태의 문장 경계성조에 의해 전달된다(Chang, 2012; Choi, 2010; Kwon, 2010; Park, 2009). 즉 종결어미의 의미
와 경계성조 간 일종의 대응관계가 성립한다. 예를 들어 '-(으) 르텐데'의 경우 추측과 아쉬움이라는 두 개의 의미를 지니는데 추측의 의미는 오름 곡선으로, 아쉬움은 내림 곡선으로 실현되 는 것이 일반적이라고 한다(Chang, 2012; Kwon, 2010; Lee, 2020). 아래의 예문에서 대화 (1)의 '-(으)르 텐데'는 추측을, 대 화 (2)는 아쉬움을 나타낸다. 따라서 (1)의 문장은 오름으로, (2) 의 문장은 내림으로 실현되는 것이 일반적이다.

*ysy0622@kyungnam.ac.kr, Corresponding author

Received 30 October 2020; Revised 15 December 2020; Accepted 15 December 2020

(C) Copyright 2020 Korean Society of Speech Sciences. This is an Open-Access article distributed under the terms of the Creative Commons Attribution NonCommercial License (http://creativecommons.org/licenses/by-nc/4.0) which permits unrestricted non-commercial use, distribution, and reproduction in any medium, provided the original work is properly cited. 
(1) 가: 미나는 뭐 하고 있을까?

나: 지금 쯤 시험치고 있을 텐데( $\nearrow$ 추측).

(2) 가: 나는 다음에 갈게.

나: 너도 같이 가면 좋을 텐데( \아쉬움)

동형다의 종결어미가 사용된 문장은 형태·통사적으로 동일 해도 문장 경계성조에 따라 의미해석이 달라진다. 예를 들어 발 화 맥락이 제거된 상태에서 (1)의 '-(으)르 텐데' 문장이 내림의 경계성조로 실현되면 아쉬움으로 해석될 수 있다.

그러나 모든 동형다의 종결어미가 의미와 경계성조 간 일대 일 대응으로 실현되는 것은 아니다. 선행 문장의 이유나 후행 문 장의 배경 설명으로 사용되는 ‘-거든(요)'의 경우 일반적으로 이 유는 내림으로, 배경 설명은 오름으로 실현되는 것으로 알려져 있다(Kwon, 2010; Lee, 2020). 그러나 이유가 오름 곡선으로, 배 경 설명이 내림 곡선으로 발화되어도 의미 전달이나 해석을 방 해하지 않는다. 선행연구에서도 내림( $\mathrm{L} \%)$ 이 이유와 배경의 억 양으로 나타나는 경우가 보고되었다(Jo, 2011; Jo, 2014; Yang \& Kim, 2019).

이처럼 동형다의 종결어미의 의미와 경계성조 간 일대 다 대 응이 가능한 것은 발화 문맥에 의존해 어느 정도 의미 해석이 가 능하다는 사실과 문장 경계성조가 동형다의 종결어미의 화용적 의미뿐만 아니라 문장 서법, 발화에 대한 화자의 태도나 감정, 공손성, 부담줄이기 등 다양한 기능을 동시에 수행하기 때문일 것이다(Kim, 2019; Park, 2016).

그럼에도 동형다의 종결어미의 서로 다른 의미가 오름과 내 림이라는 이분화된 경계성조에 의해 실현되는 경우가 있는데 그 대표적인 예로 '-(으)르 걸'을 들 수 있다. '-(으)르 걸'은 동일 한 형태로 추측과 후회라는 두 개의 의미를 전달한다. 마지막 음 절 '-걸'에 실리는 경계성조가 오름이면 추측을, 내림이면 후회 를 나타낸다(Chang, 2012; Chegal \& Kim, 2010; Kwon, 2010; Lee, 2020). 따라서 '-(으)르 걸'의 경우 의미와 경계성조가 정확히 일 대일로만 대응한다. 한국어를 학습하는 L2 학습자의 경우 '-(으) 르 걸'의 사용은 의미와 억양형태 간 대응방식의 습득을 전제로 하며 이는 의미와 억양형태의 습득이 동시에 이루어져야 함을 의미한다. 더구나 한국어의 동형다의 종결어미의 운용이 언어 보편적 현상이 아닌 만큼 한국어 원어민의 발화 관습에 대한 이 해는 한국어의 정확한 산출과 지각 그리고 성공적인 의사소통 을 위해 필수적이라 할 수 있다.

이러한 맥락에서 외국인 한국어학습자들의 한국어 동형다의 종결어미의 습득 양상을 측정하고자 다양한 연구들이 진행되었 다. 대부분의 연구들이 한국어교육에서 가장 높은 비율을 차지 하는 1 중국인학습자들을 대상으로 하였고 동형다의 종결어미 에 대한 인식 여부(Kim, 2019; Lee, 2020), 의미 인지정확도(Kim, 2019; Song, 2016; Lee, 2020), 발화정확도(Choi, 2010; Chegal \& Kim, 2009; Kwon, 2010; )를 분석하였다. 선행 연구들에서 발화
정확도는 중국인학습자들의 동형다의 종결어미 발화문의 경계 성조를 한국어 모국어화자의 경계성조와 비교·분석하여 유사 점과 차이점을 밝히고 오류 유형을 파악하는 음운론적 분석에 초점이 맞추어졌다(Chegal \& Kim, 2009; Kwon, 2010). 선행연구 들의 결과를 보면 중국인학습자들은 한국어 유창성에 상관없이 동형다의 종결어미의 의미와 억양형태를 제대로 일치시키지 못 하는 것으로 나타나며 이로 인해 동형다의 종결어미의 억양 교 수에 대한 필요성이 강조되고 있다(Chegal \& Kim, 2009; Kwon, 2010).

한편 최근에는 음운론적 분석과 음성학적 분석을 병행한 연 구들도 나오고 있다. 이들 연구들은 한국어 원어민화자와 중국 인학습자 간 동형다의 종결어미 발화에서 나타나는 음운론적 차이뿐만 아니라 음성학적 차이의 중요성도 지적하고 있다. 음 성학적 차이는 주로 경계성조의 피치변화 폭과 기울기, 선행음 절과 경계성조 간 평균 피치 편차에서 비롯되는 것으로 드러났 다(Chang, 2012; Choi, 2010; Lan, 2018; Lee, 2020; Xuan, 2013). 특히 음성학적 오류는 경계성조 산출에서 높은 오류율을 보이 는 연구(Chang, 2012; Choi, 2010; Lee, 2020)에서 뿐만 아니라 비 교적 높은 정확도를 보이는 연구(Lan, 2018; Xuan, 2013)에서도 공통적으로 지적되고 있다. 따라서 음성학적 오류는 음운론적 정확도에 상관없이 나타나고 있음을 알 수 있다. 본 연구와 관련 이 있는 ‘(으)르걸ㄹ'의 경우 동형다의 종결어미 중에서도 중국인 학습자들의 음운론적 오류 빈도가 가장 높은 종결어미로 나타 났고(Choi, 2012) 음성학적 실현에서도 한국어 모국어화자와 큰 차이를 보이는 것으로 드러났다(Lan, 2018; Lee, 2020).

이상의 선행 연구들은 외국인 학습자들의 한국어 동형다의 종결어미의 습득 과정을 밝히고 음운론적·음성학적 오류를 파 악함으로써 동형다의 종결어미의 교수과정에서 주목해야 할 운 율요소들의 상정을 가능하게 했다. 또한 동형다의 종결어미의 의미에 따른 대표억양을 상정하여 의미별 억양 유형화를 가능 하게 했다.

그러나 선행연구에서 관찰된 한국인 화자와 중국인학습자 간 동형다의 종결어미 사용에서 나타나는 유사성과 차이점이 동형다의 종결어미의 의미 변별에 청지각적으로도 유효한지에 대해서는 잘 알려져 있지 않다. 즉 중국인학습자들의 동형다의 종결어미 발화에서 나타나는 한국화자와의 음운론적·음성학적 유사성이 동형다의 종결어미의 의미 인지에 유의미한 작용을 하는지, 그리고 상이함이 실제로 의미 변별에 부정적 영향을 미 치는지에 대한 청지각적 검증은 충분히 이루어지지 못한 것이 다. 이는 대부분의 연구들이 발화 정확도를 측정하는 데 집중되 었기 때문으로 볼 수 있다. 중국인학습자들의 발화문에 대한 청 지각적 검증에 대한 연구는 '-거든'에 대한 한국인화자의 수용 가능성을 분석한 연구 $(\mathrm{Kim}, 2019)$ 정도로 시작단계에 있다.

위에서 살펴본 바와 같이 중국어권 학습자들의 동형다의 종 결어미의 발화문에 대한 음운론적·음성학적 특징은 다른 언어

1 교육부와 한국교육개발원이 발표한 ‘2020년 교육기본통계’ 자료에 따르면 중국인유학생 수는 전체 유학생 수의 $43.6 \%$ 에 달한다고 한다. 
권에 비해 상대적으로 잘 알려져 있다. 그러나 그에 대한 한국어 원어민 화자들의 수용가능성에 대한 검증은 제대로 이루어지지 못하였다. 더구나 모든 음운론적·음성학적 차이가 청지각적으 로 유효하게 작용하는 것은 아닐 수 있으므로 발화정확도 또한 원어민 화자들의 청지각적 검증을 통해 더 정확히 측정할 수 있 을 것이다.

이에 본 연구에서는 지각실험을 통해 중국인학습자들이 발 화한 동형다의 종결어미 '-(으)르 걸'의 발화문에 대한 한국어 원어민화자들의 청지각적 평가를 조사하고자 한다. 즉 중국인 화자들이 발화한 동형다의 종결어미의 경계성조에 내포된 운율 정보가 그 의미 변별에 가능하게 하는지 원어민화자들의 청지 각적 평가를 통해 살펴보고자 하는 것이다. 이와 더불어 '-(으) 르럴ㄹㅇㅢ 의미 변별에 핵심적으로 기여하는 청지각적 운율변수 가 무엇인지 피치를 중심으로 살펴볼 것이다. 그리고 이러한 과 정을 통해 동형다의 종결어미의 교수과정에 필요한 보다 유의 미한 규범적 운율 요소를 파악해 보고자 한다.

\section{2. 연구 방법}

\section{1. 실험 참가자}

본 연구의 실험자료 산출에는 중국인 한국어 학습자 10 명(남 성화자 4명, 여성화자 6명)이 참여하였다. 이들은 모두 한국어 능력시험 4-6급 합격자로 한국어 숙달도 중·고급에 해당하는 학 습자들이다. 또한 한국어 교육과정 상 '-(으)르 걸'의 두 가지 의 미를 이미 학습한 상태이다. 중국인 실험 참가자들의 평균 나이 는 21(1.56)세이며 한국대학에 재학 중인 유학생 또는 교환학생 이다. 이들의 한국어학습기간은 평균 2.8 년이다. 이들은 모두 중 국어 표준어인 보통어 구사자들이며 한국어를 발화하는 데에도 특별한 문제가 없는 화자들이다.

지각 실험에는 20 대의 한국어 원어민화자 25 명(남성 15 명, 여 성 10 명)이 참여하였다. 모두 대학에 재학 중인 학생들로 평균 나이는 22.8(2.25)세이며 경기 및 경상지역 출신이다. 지각 실험 전 연구목적과 방법을 설명하고 '-(으)르 걸'의 두 의미와 그에 따른 문미 억양의 차이를 청지각적으로 구별하고 발화할 수 있 는지 확인하였다. 청지각적 구별 능력은 연구자의 발화문(예: 나도 갈 걸 $\nearrow /$ 나도 갈 걸 \)을 듣고 '-걸'의 억양만으로 두 의미 를 변별할 수 있는지 조사하였고 발화정확도는 제시된 문장(예: 미나도 집에 있을 걸-추측/ 나도 집에 있을 걸-후회)을 추측과 후 회에 맞게 발화하는지를 연구자가 듣고 판단하면서 조사하였 다. 이 과정에서 경계성조에 의거해 '-(으)르 걸'의 의미를 청지 각적으로 변별하는 데 어려움이 있거나 의미에 따라 달라지는 경계성조를 발화하는 데 어려움이 있는 참가자는 제외되었다. 따라서 최종 실험 참가자들은 운율 변별의 청지각적 수행에 특 별한 문제가 없다. 실험 참가자들은 자발적으로 실험에 참가하
였으며 소정의 사례비를 지급받았다.

2.2. 실험자료 및 녹음

실험자료 산출에 사용된 자료는 ‘-(으)르 걸'이 추측으로 사용 된 두 문장과 후회로 사용된 두 문장으로 다음과 같다.

(1) 미나도 우산을 가져올 걸.

(2) 미나도 여섯시에 일어날 걸.

(3) 우리도 우산을 가져올 걸.

(4) 우리도 여섯시에 일어날 걸.

'-(으)륵걸'의 두 의미는 문장의 주어를 통해 유추할 수 있도 록 했다. 위의 문장은 모두 서법상 평서문의 형태를 띠지만 추측 을 나타내는 문장 (1)과 (2)는 오름의 경계성조로, 후회 문장인 (3) 과 (4)는 내림의 경계성조로 발화되어야 한다.

녹음은 소음이 적은 조용한 방에서 개인별로 실시하였다. SONY사의 디지털 녹음기 ICD_SX713과 내장마이크를 사용하 여 44,000 Hz, 16 bit 모드로 실험 문장을 녹음하였다. 녹음이 시 작되기 전 연구의 목적을 설명하고 녹음 자료를 나누어 준 후 각 문장에서 '-(으)르 걸'이 내포하는 의미를 파악하게 하였다. 대 부분의 학습자들은 문장의 주어를 통해 의미를 정확히 파악하 였다. 그러나 필요한 경우 부연 설명을 통해 '-(으)르 걸'의 의미 를 변별할 수 있게 했다. 각 문장에 대한 정확한 의미 파악을 확 인한 후, 충분한 발화 연습시간을 가지도록 했다. 쌍을 이루는 두 문장(1)-(3), (2)-(4))의 의미가 문미 억양 즉 경계 성조에 의 해 달라짐을 각자 알고 있는 방식으로 발화하도록 주문했고 문 미 억양의 발화 방식에 대해서는 어떠한 정보도 제공하지 않았 다. 녹음 참가자들은 각 문장을 보통 속도로 6회 반복 발화하였 는데 발화오류(분절음 오류, 더듬거림, 잘못 읽음 등)가 나타나 는 경우 6회를 초과해 발화하였다. 각 문장의 반복 발화 분 중 음 질이 좋고 억양 곡선이 잘 드러나는 4회를 선정하여 분석 자료 로 사용하였다. 그 결과 분석에 사용된 문장은 10 명의 화자가 4 개의 문장을 4 회 반복한 총 160 문장이다.

\section{3. 지각실험}

중국인학습자들이 산출한 발화문은 추측과 후회의 문장으로 분리되었고 다시 남성화자와 여성화자로 구분하여 총 8 개의 지 각실험 자료 (남성 추측 (a), (b), 여성 추측 (a), (b), 남성 후회 (a), (b), 여성 후회 (a), (b)를 구성하였다. 각 세트 안에서는 (1)과 (2), 또는 (3)과 (4)의 문장이 반복되도록 하였다2. 지각 실험 자료는 중국인 남성과 여성화자가 산출한 문장을 분리하여 구성하였는 데 남성과 여성의 음역대가 다르므로 이러한 차이가 청지각적 판별에 영향을 줄 수 있을 것으로 판단하였기 때문이다.

지각실험은 한국어 원어민을 상대로 하였고 Praat script MFC

2 사전 실험에서 추측(1), (2)과 후회(3), (4)문장을 혼합하여 두 명의 실험참가자들에게 제시하였는데 선택의 어려움을 초래하여 본 실험에서는 추 측과 후회로 분리하여 제시하였다. 사전 실험참가자들은 본 실험에는 참가하지 않았다. 
Experiment를 통해 개인별로 실시되었다. 실험이 시작되면 참가 자들은 Praat script MFC Experiment가 실행된 모니터 앞에 앉아 이어폰으로 청취 자료를 한 문장씩 들으면서 문장 경계성조의 운율정보에만 기대어 '-(으)르 걸'의 의미와 정확도를 판별하였 다. 지각실험 문장은 표적 단위만을 추출하여 들려주지 않고 문 장 전체를 들려주었다. 문장에서 필요한 부분만을 선택할 경우 발화문의 시작점부터 이어지는 피치 곡선이 끊어짐으로 청지각 적으로 부자연스러운 피치가 생성될 수 있고 이는 지각 판별에 부정적 영향을 줄 수 있을 것으로 보았다. 그 때문에 문장의 통 사나 의미 정보가 ‘-(으)르 걸’의 의미 판별에 영향을 줄 수 있겠 지만 문장 경계성조가 실리는 '-걸'의 억양에만 집중하여 의미 를 판별하도록 주문하였다. 그럼에도 불구하고 실험문장에서 문두의 주어가 ‘-(으)르 걸'의 의미 판별에 미칠 수 있는 영향을 완전히 배제할 수는 없을 것이다. 즉 청자가 문장을 끝까지 듣지 않고 문두의 주어만으로 '-(으)르 걸'의 의미를 판단할 수도 있 다는 것이다. 이런 문제를 해결하고자 결과분석에서 응답시간 이 실험문장 시간보다 짧은 응답은 분석에서 제외하였다. 3

지각 판별은 5 개 항목으로 ‘(1) 정확한 후회, (2) 후회 (3) 모호 함, (4) 추측, (5) 정확한 추측' 중 하나를 선택하도록 하였다. 각 세트는 20 문장 내외로 구성되었으며 필요한 경우 각 세트 사이 에 휴식을 취하도록 하였다. 문장 간 이동은 위에 제시된 5 개의 항목 중 하나를 선택하면 자동으로 이루어지도록 했다. Replay 버튼은 5회까지 누를 수 있게 했다. 즉 절대적 시간 안에 강제 선 택하는 방법이 아니라 '-(으)르 걸'의 의미를 문장 경계성조에 의거해 판단할 수 있는 충분한 시간이 제공되도록 했다4. 이러 한 지각실험 방법은 한국어문미 억양의 의미 변별(Oh, 2011)과 발화 속도(Nam, 2020)를 측정하는 선행연구에서도 사용되었다.

\section{4. 운율 변수}

동형다의 종결어미의 청지각적 의미판별과 관련된 운율 특 징은 피치를 중심으로 살펴보았다. 즉 문장 경계성조, 문장 경계 성조의 기울기, 문장 경계성조와 선행음절 간 피치편차, 문장 경 계성조의 피치레벨(pitch level) 등 네 개의 운율변수를 분석하였 다. 이들 변수 중 문장 경계성조, 즉 ‘-(으)르 걸'의 마지막 음절 ‘걸'에 실리는 경계성조가 음운론적 유형이라면 나머지 세 운율 변수는 경계성조의 음성학적 실현과 관련된다. L2 억양 분석에 서 음운론적 층위와 음성학적 층위의 분리 필요성은 Jun \& $\mathrm{Oh}$ (2000)와 Mennen(2004)에서도 언급되었다. 각 운율변수의 측 정 기준은 다음과 같다.

문장 경계성조는 전통적으로 동형다의 종결어미의 의미를 결정짓는 중요한 운율 변수였다. 본 연구에서 경계성조는
$\operatorname{Jun}(2000)$ 의 연구에 따라 9개의 경계성조인 $\mathrm{H} \%, \mathrm{~L} \%, \mathrm{LH} \%$, $\mathrm{HL} \%, \mathrm{LHL} \%, \mathrm{HLH} \%, \mathrm{HLHL} \%, \mathrm{LHLH} \%, \mathrm{LHLHL} \%$ 로 구분하였 다. 이를 바탕으로 문장 경계성조의 형태가 동형다의 종결어미 의 의미 판별에 어떤 영향을 미치는지 지각평점과의 관계를 분 석하였다. 문장 경계성조의 기울기는 기울기의 방향과 크기가 '-(으)르 걸'의 의미 변별에 영향을 미치는지 살펴보고자 분석하 였다. 기울기는 경계성조의 형태에 따라 다르게 측정되었는데 $\mathrm{H} \%$ 와 $\mathrm{L} \%$ 의 경우 시작점과 끝점을 기준으로, $\mathrm{LH} \%$ 의 경우 피치 곡선의 오름이 시작되는 지점과 끝점을 기준으로 각 지점의 피 치와 시간을 측정하여 산출하였다. 일반적으로 추측의 경우 기 울기가 0 을 기준으로 양의 방향으로 커지며, 후회의 경우 음의 방향으로 작아질 것으로 예측할 수 있다. 문장 경계성조와 선행 음절 간 피치 편차는 선행연구에서 한국인화자와 중국인학습자 의 동형다의 종결어미 발화문에서 관찰되는 중요한 음성학적 차이로 지적되었다(Jegal \& Kim, 2009; Lan, 2018). 따라서 본 연 구에서는 경계성조와 선행음절의 피치편차가 '-(으)르 걸'의 의 미 변별에 청지각적으로도 유의미하게 작용하는지 그 영향력을 살피고자한다. 두 음절의 피치편차는 경계성조의 평균 음높이 에서 선행음절의 평균 음높이를 차감하여 그 차이 $(\mathrm{Hz})$ 를 Qt(quarter tone)으로 변환하여 산출하였다. 따라서 두 음절의 피 치편차는 추측의 경우 양의 값으로 커지며, 후회의 경우 음의 값 으로 작아질 것이다. 문장 경계성조의 피치레벨은 각 화자의 음 역대에서 문장 경계성조가 위치하는 피치 대역을 파악하기 위 해 측정되었다. 이 값은 경계성조의 평균 음높이에서 문장의 평 균 음높이를 차감하여 그 차이 $(\mathrm{Hz})$ 를 $\mathrm{Qt}$ 으로 변환하여 구하였 다. 경계성조의 피치레벨은 추측의 경우 양의 값으로, 후회의 경 우 음의 값으로 도출될 것이므로 후회와 추측의 경계성조가 위 치하는 상대적인 음역대를 파악할 수 있을 것이며 이 변수가 지 니는 청지각적 영향력도 파악할 수 있을 것이다. 상기된 네 개의 운율변수는 각 문장 별로 측정되었다. 위에서 제시된 각각의 운 율변수와 '-(으)르 걸'의 의미 지각과의 관계는 교차분석과 분산 분석 그리고 로지스틱 회귀분석을 통해 살펴볼 것이다. 지각평 점과 경계성조와의 관계는 교차분석을 통해 조사하고 지각평점 과 경계성조의 기울기, 경계성조와 선행음절 간 피치편차, 경계 성조의 피치레벨과의 관계는 분산분석을 통해 지각판단 별로 평균값의 차이를 살펴볼 것이다. 그리고 이항 로지스틱 회귀분 석을 통해 지각판단에 유의미한 영향력을 미치는 운율변수가 무엇인지 조사할 것이다.

3 응답시간이 실험문장 시간보다 짧다고 해서 청자가 문장을 끝까지 듣지 않고 중간에 응답을 했다고 볼 수는 없다. Praat script MFC Experiment의 경 우 Replay 버튼을 눌러 반복 듣기를 하거나 응답버튼을 잘못 눌러 'go back'을 하는 경우 이전 시간이 반영되지 않으므로 시간이 짧게 나올 수 있다. 4 본 연구에서는 청자의 정확한 판단이 중요하다고 여겼기에 응답시간을 제한하지 않았다. 응답시간이 길어져 생각하는 시간이 길어질수록 답이 달 라질 수도 있으나 청자의 최종 판단과 그 판단을 유도하는 운율적 단서의 관계가 중요하다고 판단되었다. 지각판단에서 청자가 원하는 만큼 답변 시간을 가질 수 있는 방법은 상기된 선행연구에서도 사용되었다. 


\section{3. 결과}

3.1. 지각과 경계성조

상기한 바와 같이 경계성조는 동형다의 종결어미의 의미를 결정짓는 중요한 운율변수이다. 본 연구의 중국인학습자들이 추측과 후회로 발화한 '-(으)르 걸' 문장에서 나타난 경계성조 는 $\mathrm{H} \%, \mathrm{LH} \%, \mathrm{~L} \%$ 이다. 이러한 경계성조의 형태가 동형다의 종 결어미의 의미 지각과 어떤 관련성이 있는지 살펴보았다. 결과 는 총 4,000 개의 지각판단 중 반응시간이 실험문장보다 짧은 응 답은 제외된 3,965 개의 응답을 대상으로 하였다. 결과는 표 1 에 제시되었다. 표 1 에서 오름은 $\mathrm{H} \%$ 와 $\mathrm{LH} \%$ 를, 내림은 $\mathrm{L} \%$ 을 포함 한다.

표 1. 지각과 경계성조 교차표

Table 1. Cross table analyze between perception and boundary tones

\begin{tabular}{c|c|c|c|c|c|c|c}
\hline \multicolumn{2}{c|}{} & \multicolumn{5}{|c|}{ 정확도 } & \multirow{2}{*}{} \\
\cline { 2 - 7 } \multicolumn{2}{c|}{} & $\begin{array}{c}\text { 정확한 } \\
\text { 후회 }\end{array}$ & 후회 & 모호 & 추측 & $\begin{array}{c}\text { 정확한 } \\
\text { 추측 }\end{array}$ & 전체 \\
\hline 경 & 오름 빈도 & 118 & 150 & 116 & 794 & 989 & 2,167 \\
계 & 경 계성조 중 $\%$ & $5.4 \%$ & $6.9 \%$ & $5.4 \%$ & $36.6 \%$ & $45.6 \%$ & $100 \%$ \\
\cline { 2 - 7 } 성 & 내림 빈도 & 405 & 911 & 294 & 127 & 61 & 1,798 \\
조 & 경 계성조 중 \% & $22.5 \%$ & $50.7 \%$ & $16.4 \%$ & $7.1 \%$ & $3.4 \%$ & $100.0 \%$ \\
\hline 전 & 빈도 & 523 & 1,061 & 410 & 921 & 1,050 & 3,965 \\
체 & 경 계성조 중 $\%$ & $13.2 \%$ & $26.8 \%$ & $10.3 \%$ & $23.2 \%$ & $26.5 \%$ & $100.0 \%$ \\
\hline
\end{tabular}

중국인 학습자들이 발화한 전체 160 문장 중 경계성조가 오름 ( $\mathrm{H} \%, \mathrm{LH} \%)$ 으로 발화된 문장은 87 문장, 내림(L\%)으로 발화된 문장은 73 문장이다. 오름 87 문장과 내림 73 문장에 대한 원어민 화자 25 명의 지각실험 결과 오름 곡선에 대한 지각 판단 2,167 개, 내림 곡선에 대한 지각 판단 1,798 개가 생성되었다. 오름 곡 선에 대한 2,167 개의 판단 중 추측(정확한 추측 또는 추측)으로 인지된 경우는 $82.3 \%(1,783 / 2,167)$, 오름 곡선임에도 불구하고 후회로 인지된 경우는 $12.4 \%(268 / 2,167)$, 모호함은 $5.3 \%(116 /$ 2,167)이다.

내림 곡선에 대한 1,798 개의 지각 판단 중 후회(정확한 후회 또는 후회)로 인지된 비율은 $73.2 \%(1,316 / 1,798)$, 내림곡선이 추 측으로 인지된 경우는 $10.5 \%(188 / 1,798)$, 모호함 즉 판별 불가로 지각된 경우는 $16.3 \%(294 / 1,798)$ 로 상대적으로 높게 나타났다.

결과적으로 전체 지각 판단 중 약 $78.2 \%(3,099 / 3,965)$ 는 오름 의 경계성조는 추측으로, 내림의 경계 성조는 후회로 인지되었 다. 따라서 모든 오름 곡선이 추측으로, 또는 모든 내림 곡선이 후회로 지각된 것은 아님을 알 수 있다. 그러나 교차분석 결과 경계성조 유형이 추측과 후회 문장의 의미 판별과 유의미한 관 계가 있는 것으로 나타났다 $\left(\chi^{2}=2,067.387, p<.001\right)$.

\section{2. 지각과 경 계성조의 기울기}

문장 경계성조의 기울기의 방향과 크기가 '-(으)를 걸의 의미 변별에 영향을 미치는지 살펴보고자 지각평점과 그에 따른 경 계성조 기울기의 평균을 비교·분석하였다. 결과는 그림 1 에 제 시되었다. 그림에서 가로축의 $1-5$ 는 각각 정확한 후회(1), 후회
(2), 모호함(3), 추측(4), 정확한 추측(5)으로 지각판단 항목을 나 타내며 세로축은 기울기 $(\mathrm{Hz} / \mathrm{ms})$ 를 나타낸다.

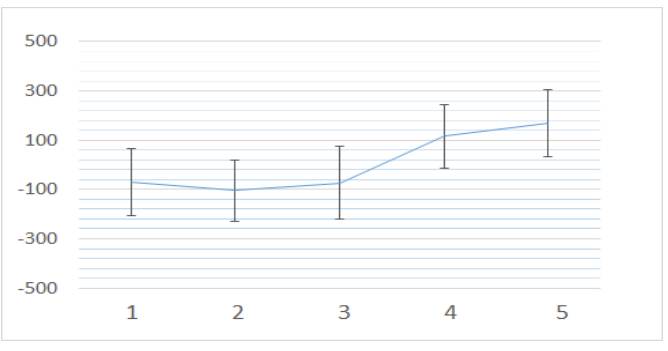

그림 1. 지각과 경계성조의 기울기 $(\mathrm{Hz} / \mathrm{ms})$

Figure 1. Perceptual rating and slope of boundary tones

지각판단에 따른 평균 기울기 값은 정확한 후회(1) -70.98 , 후 회(2) -104.95 , 모호함(3) -74.11 , 추측(4) 115.45 , 정확한 추측(5) 169.07로 나타났다. 예상과 달리 정확한 후회(1)보다 후회(2)의 기울기가 음의 방향으로 작아졌으며 모호함(3)으로 지각된 문 장의 기울기가 정확한 후회(1)로 지각된 문장들의 기울기와 유 사한 값을 보임을 알 수 있다. 그러나 위의 그림 1 을 통해 일반적 으로 0 을 기준으로 평균 기울기가 양의 방향으로 커질 때 평점 은 5(정확한 추측)에 가까워지며 음의 방향으로 작아질 때 평점 2(후회)에 가까워지는 경향을 발견할 수 있다. 따라서 오름 곡선 으로 기울기가 클수록 추측으로, 내림 곡선으로 기울기가 낮을 수록 후회로 지각된다고 할 수 있다. 지각판단에 따른 기울기 간 차이가 유의미한지 살펴보고자 지각과 기울기 간 일원배치분산 분석을 실시했다. 분석 결과 지각판단에 따른 기울기 값은 유의 미한 차이가 나타났다 $[F(4,3,964)=802.007, p<.001]$. 사후분석 (Tukey HSD) 결과 정확한 후회(1)와 모호함(3) 간 유의확률 $(p=996)$ 을 제외하면 모든 그룹에서 유의미한 차이를 보였다 $(p<.001)$. 그러나 상기한 바와 같이 정확한 후회(1)보다 후회(2) 의 기울기가 음의 방향으로 더 작아졌음을 결과해석에 감안해 야 한다.

\section{3. 지각평점과 피치편차}

중국인학습자들의 동형다의 종결어미의 발화에 대한 선행연 구에서 원어민 화자와의 음성학적 차이가 가장 크게 드러난 운 율변수로 선행음절과의 피치편차가 거론되었다(Lan, 2018). 본 연구에서는 두 음절 간 피치편차가 의미지각에도 유의미한 작 용을 하는지 살펴보고자 지각판단과 그에 따른 피치편차의 평 균값을 비교하였다. 결과는 그림 2에 제시되었다. 그림 1에서와 마찬가지로 가로축은 지각판단(1-5)을 나타내며 세로축은 피치 편차(-10-15Qt)를 나타낸다. 


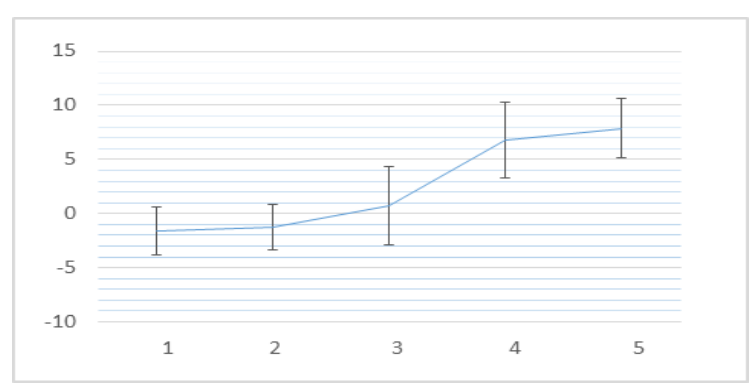

그림 2. 지각에 따른 피치편차의 평균값( $(\mathrm{Qt})$

Figure 2. Perceptual rating and pitch differences between boundary and penultimate syllables

지각판단에 따른 평균 피치편차 값은 정확한 후회(1) -1.59 , 후회(2) -1.31 , 모호함(3) -0.68 , 추측(4) 6.79 , 정확한 추측(5) 7.87 로 나타났다. 피치편차 값과 그림 2 를 통해 알 수 있듯이 피치 편 차의 평균값이 0 을 기준으로 양의 방향으로 커질수록 추측으로, 음의 방향으로 작아질수록 후회로 지각되는 경향을 명확히 볼 수 있다. 또한 모호함으로 지각된 문장의 평균 피치편차는 0에 가까워짐을 알 수 있다. 지각판단에 따른 피치편차의 평균값이 유의미한 차이를 보이는지 살펴보고자 지각과 피치편차 간 일 원배치분산분석을 실시했다. 분석 결과 피치편차 값은 지각판 단에 따라 유의미한 차이가 있는 것으로 나타났다 $[F(4,3,964)=$ 2,220.107, $p<.001]$. 사후분석(Tukey HSD) 결과 정확한 후회(1) 와 후회(2) 간의 유의확률 $(p=.314)$ 을 제외하면 모든 그룹에서 유 의미한 차이를 보인다 $(p<.001)$.

\section{4. 지각과 피치레벨}

추측과 후회로 발화되는 '-(으)르 걸’의 경계성조는 후회의 경 우 화자의 음역대 중 비교적 낮은 위치에서, 추측의 경우 상대적 으로 높은 위치에서 실현될 것이다. 경계성조의 피치 레벨이 추 측과 후회의 의미 인지에 영향을 미치는지 살펴보기 위해 지각 판단에 따른 피치레벨의 평균값을 비교하였다. 결과는 그림 3에 제시되었다. 그림에서 가로축과 세로축은 각각 지각판단(1-5) 과 피치레벨(-15-15Qt)을 나타낸다.

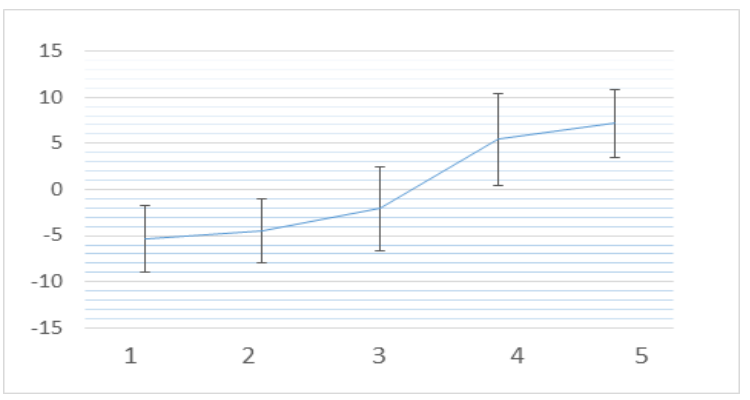

그림 3. 지각에 따른 피치레벨의 평균값( $(\mathrm{Qt})$

Figure 3. Perceptual rating and pitch level of boundary tones
그림 3을 통해 알 수 있듯이 후회(정확한 후회, 후회)로 지각 된 문장들의 경계성조는 문장평균보다 낮은 위치에서, 추측(정 확한 추측, 추측)으로 지각된 문장들의 경계성조는 문장 평균보 다 높은 위치에서 실현되고 있다. 지각판단에 따른 평균 피치레 벨 값을 좀 더 자세히 살펴보면 정확한 후회(1) -5.40, 후회(2) 4.44 , 모호함(3) -2.08 , 추측(4) 5.43, 정확한 추측(5) 7.14로 나타 났다. 지각판단에 따른 피치레벨 값의 유의성을 알아보고자 일 원배치분산분석을 실시했다. 분석결과 지각판단에 따른 피치편 차 값은 유의미한 차이가 관찰되었다 $[F(4,3,964)=1,750.993$, $p<.001]$. 사후분석(Tukey HSD) 결과 또한 모든 그룹에서 유의미 한 차이를 보였다 $(p<.001)$.

\section{5. 지각판단과 운율변수}

지금까지 살펴본 문장 경계성조, 기울기, 피치편차와 피치레 벨은 '-(으)르 걸'의 의미 지각 유형에 따라 평균값에 유의미한 차이가 있음을 보여주었다. 본 장에서는 '-(으)르 걸'의 의미 판 별, 즉 지각에 영향을 미치는 운율변수들의 상대적 영향력을 살 펴보고자 한다. 이를 위해 지각판단을 종속변수로, 경계성조, 기 울기, 피치편차, 피치레벨을 독립변수로 이항 로지스틱 회귀분 석을 실시하였다. 이항 로지스틱 회귀분석을 위해 5항으로 된 지각판단에서 모호함(3)을 제외하고 정확한 후회와 후회를 묶 어 0 으로, 정확한 추측과 추측을 묶어 1 로 상정하여 분석하였다. 경계성조 역시 오름 $(\mathrm{H} \%, \mathrm{LH} \%)$ 과 내림(L\%) 두 그룹으로 묶어 오름을 0 으로 내림을 1 로 지정하여 분석하였다. 분석 결과는 표 2에 제시되었다.

표 2. 지각과 운율변수 간 로지스틱 회귀분석

Table 2. Results of logistic regression analysis

\begin{tabular}{c|c|c|r|r|c|c}
\hline & $\mathrm{B}$ & $\mathrm{SE}$ & \multicolumn{1}{c|}{ Wald } & 자유도 & $\begin{array}{c}\text { 유의 } \\
\text { 확률 }\end{array}$ & $\begin{array}{c}\text { 승산비 } \\
(\operatorname{Exp}(\mathrm{B}))\end{array}$ \\
\hline 경계성조 & .092 & .263 & .123 & 1 & .726 & 1.097 \\
\hline 기울기 & .000 & .001 & .237 & 1 & .627 & 1.000 \\
\hline 피치편차 & .765 & .060 & 164.155 & 1 & .000 & 2.148 \\
\hline 피치레벨 & -.003 & .032 & .009 & 1 & .924 & .997 \\
\hline 상수항 & -1.771 & .460 & 14.792 & 1 & .000 & .170 \\
\hline
\end{tabular}

결과를 살펴보면 4개의 운율 변수 중 ‘-(으)르 걸'의 의미 판별 (지각판단)에 유의미한 영향을 미치는 변수는 피치편차 $(p<.001)$ 임을 알 수 있다. 나머지 변수인 경계성조, 기울기, 피치레벨은 지각판단에 유의미한 영향을 미치지 못하고 있다. 피치편차의 승산비를 통해 피치편차가 $1 \mathrm{Qt}$ 높아질수록 지각판단이 후회에 서 추측으로 될 확률은 2 배 상승한다고 예측할 수 있다 $(\mathrm{OR}=$ $2.148, \beta=.765)$. 이는 후회와 추측의 의미 변별은 경계음절과 선행 음절 간 피치편차에 의해 더 명확히 지각될 수 있음을 의미한다.

일반적으로 '-(으)ㄹㄱ걸'의 의미판별에 가장 큰 영향을 미치는 운율변수는 경계성조로 알려져 있다. 경계성조가 내림이면 후 회로, 오름이면 추측으로 해석된다. 그러나 위의 결과는 경계성 조 외에 음성학적 변인인 피치편차가 ‘-(으)르 걸’의 의미변별에 핵심적인 영향을 미칠 수 있음을 보여준다. 이런 사실은 아래의 
그림 4 와 그림 5 를 통해서도 확인할 수 있다.

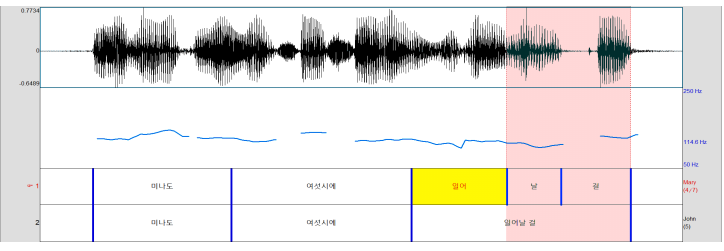

그림 4. '-(으)르 걸' 문장의 피치곡선(추측) Figure 4. Pitch contour of ‘-(eu)lgeol' sentence(guess)

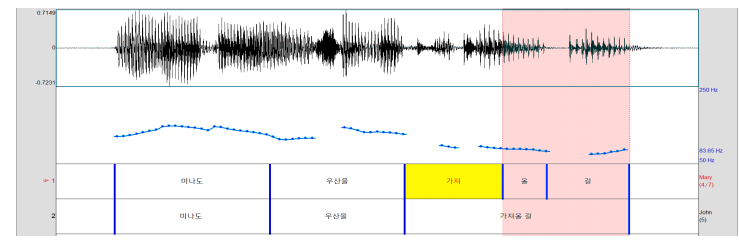

그림 5. '-(으)르 걸' 문장의 피치곡선(추측)

Figure 5. Pitch contour of '-(eu)lgeol' sentence(guess)

두 그림은 모두 '-(으)르 걸'이 추측으로 발화된 문장의 피치 곡선이다. 문장의 마지막 음절인 '-걸'의 경계성조는 그림 4에서 는 내림으로, 그림 5에서는 오름으로 발화되었다. 지각실험 결 과 내림의 경계성조로 발화된 그림 4 의 문장은 25 명의 지각실험 참여자 중 22 명이 추측(4) 또는 정확한 추측(5)으로 지각해 평균 4.08의 평점으로 추측 문장으로 지각되었다. 그 반면 오름의 경 계성조로 발화된 그림 5의 문장은 25 명중 19 명이 후회(2)나 정 확한 후회(1)로 지각해 1.92의 평점으로 후회 문장으로 지각되 었다. 이는 '-(으)르 걸'의 의미가 경계성조에 의해서만 결정되 는 것이 아님을 방증한다. 이처럼 경계성조의 형태에서 예측되 는 것과 상반된 지각판단이 가능한 것은 무엇보다 선행음절과 경계음절의 피치편차 때문이라고 할 수 있다. 그림 4와 그림 5의 문장에서 경계음절과 선행음절 간 피치편차는 각각 5.69Qt과 3.28Qt로 피치편차가 ‘-(으)르 걸’이 추측으로 지각되는지 후회 로 지각되는지에 큰 영향을 미친다는 사실을 표 2 를 근거로 설 명할 수 있다.

이러한 결과는 '-(으)르 걸'의 억양교육에도 시사하는 바가 크 다고 하겠다. 위의 결과를 발화 관점에서 본다면 마지막 두 음절 에 대한 보다 지엽적인 피치 조정으로 '-(으)르 걸'의 서로 다른 두 의미를 구별하여 발화할 수 있음을 의미하기 때문이다. 전통 적으로 '-(으)르 걸'의 억양은 경계성조의 형태에 초점이 맞추어 졌지만 청지각적 관점에서 본다면 그 보다는 경계음절과 선행 음절 간 피치 편차가 의미 판별에 강한 영향력을 주고 있음을 알 수 있다.

\section{4. 결론}

본 연구에서는 중국인한국어학습자들이 산출한 한국어 동형 다의 종결어미 ‘-(으)르 걸'의 발화문에 대한 한국어 원어민 화 자들의 지각 양상을 분석하였다. 지금까지 외국인 학습자들의 동형다의 종결어미의 발화 양상은 주로 문장 경계성조의 형태
에 초점이 맞추어진 음운론적 분석이나 원어민 화자와의 음성 학적 차이에 초점이 맞추어졌다. 그러나 이러한 음운론적·음성 학적 유사성과 차이점이 동형다의 종결어미의 의미 변별에 어 떤 작용을 하는지 그리고 의미 변별에 핵심적인 역할을 하는 청 지각적 운율변수가 무엇인지에 대해서는 잘 알려져 있지 않았 다. 이러한 사실은 동형다의 종결어미의 억양 이해에 한계를 이 룬다고 할 수 있다.

본 연구에서는 동형다의 종결어미의 의미 변별과 운율 변수 간 관계를 살피고자 문장 경계성조와 더불어 경계음절의 기울 기, 경계음절과 선행음절 간 피치 편차, 경계음절의 피치레벨을 분석하였다. 분석 결과 경계성조, 경계성조의 기울기, 피치편차, 피치레벨이 모두 의미 지각과 유의미한 관련성이 있다는 것을 알 수 있었다. 그러나 이들 중 ‘-(으)르 걸'의 의미 지각에 유의미 한 작용을 하는 운율변수는 피치편차임을 알 수 있었다.

본 연구는 청지각적 분석에 집중하였으나 그 결과는 발화정 확도 판정이나 동형다의 종결어미의 억양 교육에도 의미 있는 시사점을 제시한다고 할 수 있다. 즉 외국인학습자들의 동형다 의 종결어미의 발화정확도를 평가하는 과정에서 경계성조의 형 태만을 기준으로 하는 음운론적 접근보다는 실제 발화에서 나 타나는 음성학적 차이점에 대한 분석도 병행되어야 한다는 것 이다. 문장 경계성조의 형태만으로 발화정확도를 판정하는 것 은 판정의 오류를 범할 수 있으며 정확한 오류 유형을 파악하는 것이 불가능할 수도 있기 때문이다. 또한 본 연구 결과를 발화측 면에서 본다면 동형다의 종결어미의 마지막 음절과 선행음절 간 지엽적인 피치 조정으로 '-(으)르 걸'의 두 의미를 구별하여 발화할 수 있음을 의미한다. 이는 '-(으)르 걸'의 억양교육에서 보다 객관적이고 유의미한 규범적 운율 요소로 적용될 수 있을 것이다.

그러나 본 연구는 제한된 피험자와 실험 자료를 대상으로 하 였고 운율변수 간 상호작용이 다각적으로 분석되지 못했다는 한계도 있다. 따라서 본 연구의 결과를 일반화하기에는 무리가 있다. 특히 피치편차와 경계성조와의 상호작용이나 상호보완 가능성에 대한 분석은 후속연구를 통해 반드시 밝혀져야 할 필 요가 있다.

\section{References}

Choi, J. (2010). A study for pragmatic intonation types of final endings for Korean language education: Targeting at advanced Chinese Learner (Master's thesis). Kyunghee University, Korea.

Chang, J. (2012). An experimental study on intonation pattern of Korean polysemous final-endings (Master's thesis). Hankuk University of Foreign Studies, Korea.

Chegal, M., \& Kim S. J. (2010). The analysis of Chinese Learner's Korean intonation for intonation education plan based on the functions of pragmatics. Journal of Education \& Culture, 16(2), 191-215.

Jo, M. (2011). A study on the finalizing function of connective endings 
and the role of intonation: mainly based on the utterancecompleting function of connective endings and the role of intonation (Doctoral dissertation). Korea University, Korea.

Jo, M. (2014). Pragmatic strategy and intonation of '-geodeun', the final endings: focusing on the age variation of those in $10 \mathrm{~s}, 20 \mathrm{~s}$, 30s. Korean Linguistics, 65, 237-262.

Jun, S. A. (2000). K-ToBI (Korean ToBI) labelling conventions. Retrieved form https://inguistics.ucla.edu/people/jun/ktobi/ktobi 3-2.pdf

Jun, S. A., \& Oh, M. (2000). Acquisition of second language intonation. 6th International Conference on Spoken Language Processing, ICSLP 2000 (Inter-speech 2000) (pp. 73-76). Beijing, China.

Kim, J. (2019). A study on use of the connective ending and closing ending -ketun by Chinese speakers and the response of Korean speakers (Master's thesis). Ewha Womans University, Korea.

Kwon, S. (2010). A study of interlanguage intonation manifested in non-final endings that behave like final endings. Journal of Korean Language Education, 21(4), 1-23.

Lan, Q. (2018). A study on Korean language intonation for Chinese speaking learners-with focus on '-damyonseo, -oelgeol, -geadon, -eolthenda' (Master's thesis). Seoul National University, Korea.

Lee, J. (2020). A study on teaching Korean final endings' intonation (Doctoral dissertation). Pusan National University, Korea.

Mennen, J. (2004). Bi-directional interference in the intonation of Dutch speakers of Greek. Journal of Phonetics, 32(4), 543-563.

Nam, H. (2020). Perception of speech rate in Korean (Master's thesis). Korea University, Korea.

Oh, J. (2011). A perceptual study of the grammatical function and phonetic features on the intonation of utterance final in Korean (Doctoral dissertation). Korea University, Korea.

Park, J. (2016). A study on the intonation of ending word '-neunde' and '-geodeun' attached to sentence final ending functioning as burden-reduction. Bilingual Research, 64, 1-20.

Park, K. (2009). The study of teaching Korean final endings' intonation: A focus on intonation difference of modal meanings. Journal of Korean Language \& Literature, 34, 373-397.

Song, Y. (2016). An experimental phonetic study on intonation patterns and perception of Korean polysemous final-endings by Chinese learners (Master's thesis). Hankuk University of Foreign Studies, Korea.

Xuan, X. (2013). Experimental phonetic study on Chinese learners' intonation of Korean connective ending functioning as final endings (Master's thesis). Hanyang University, Korea.

Yang, S., \& Kim, Y. (2019). Intonation of Korean final endings '-koden'-Examples from native speakers and topik level 6 learners-. New Language Education, 121, 411-442.
- 윤영숙 (Youngsook Yune) 교신저자

경남대학교 교양융합대학 교수

경남 창원시 마산합포구 경남대학로 7

Tel: 055-249-6322

Email: ysy@kyungnam.ac.kr

관심분야: 음성학, 음운론, 인지 언어학 


\title{
$\mathrm{KFL}$ 중국인학습자들의 한국어 동형다의 종결어미 발화문에 대한 원어민화자의 지각 평가 양상
}

\author{
윤 영 숙
}

경남대학교 교양융합대학

\begin{abstract}
국문초록
본 논문은 중국인 한국어학습자들이 발화한 한국어 동형다의 종결어미 ‘-(으)르 걸’ 대한 한국어 원어민화자들의 지각양상을 분석하고 이를 바탕으로 '-(으)르 걸'의 청지각적 의미 변별에 결정적인 역할을 하는 운율변수를 한국 어 교육적 관점에서 분석하는 데 목적이 있다. 동형다의 종결어미는 하나의 형태로 두 개 이상의 의미를 전달하는 종결어미를 일컫는다. 지금까지 외국인학습자들을 대상으로 한 동형다의 종결어미에 대한 연구는 외국인학습자 들의 발화문을 원어민 화자의 발화문과 비교·분석하여 음운론적·음성학적 유사점과 차이점을 분석하여 발화정확 도나 오류유형을 측정하는 데 집중되었다. 이로 인해 원어민화자와의 유사성과 차이점이 '-(으)르 걸'의 의미 판별 에 실제로 유의미한 작용을 하는지에 대한 청지각적 연구는 이루어지지 못했다. 본 연구에서는 중국인 한국어학습 자들의 동형다의 종결어미 문장이 한국어 원어민화자들에게 어떤 양상으로 지각되는지 분석하여 동형다의 종결 어미 억양교육에 필요한 운율 규범을 상정해 보고자 한다. 본 연구의 실험자료 산출에는 한국어 숙달도 중·고급에 해당하는 10 명의 중국인 한국어학습자들이, 지각 실험에는 20 대의 한국인 원어민화자들이 참가하였다. 분석 자료 는 '-(으)륵ㄱㄹㄹ'이 추측으로 사용된 두 문장과 후회로 사용된 두 문장이다. 10 명의 중국인화자들이 4 개의 실험문장 을 4 회 반복 발화분이 지각실험 자료로 사용되었다. 지각실험참가자들은 실험 자료를 들으면서 문장 경계성조의 억양에만 의존하여 ‘-(으)르 걸'의 의미와 정확성 정도를 판별하였다. 25 명의 청취실험자들의 지각실험 결과를 바 탕으로 정확한 추측, 추측, 모호함, 후회, 정확한 후회로 지각된 문장들의 운율변수, 즉 경계성조, 경계성조의 기울 기, 경계음절과 선행음절 간 피치편차, 경계음절의 피치레벨을 측정하였다. 통계분석 결과 상기된 모든 운율변수 가 '-(으)르 걸'의 의미변별과 유의미한 관련이 있음을 알 수 있었다. 즉 운율변수가 커질수록 추측으로 작아질수록 후회문장으로 지각됨을 관찰할 수 있었다. 그러나 로지스틱 회귀분석을 통해 의미변별에 가장 핵심적인 역할을 수 행하는 운율변수는 피치편차임을 알 수 있었다. 이러한 결과는 '(으)ㄹ 걸'의 발화에서 마지막 두 음절의 피치 조절 로 두 의미를 변별하여 발화할 수 있음을 의미하며 '-(으)르 걸'의 억양교육에서 보다 객관적이고 유의미한 규범적 운율 요소로 적용될 수 있을 것이다.
\end{abstract}

핵심어: 동형다의 종결어미, 지각실험, 문장 경계성조, 피치 편차, 제 2언어 억양

\section{참고문헌}

권성미 (2010). 연결어미의 종결어미적 쓰임에 나타나는 억양의 중간 언어 연구. 한국어 교육, 21(4), 1-23.

김지연 (2019). 중국어권 한국어 학습자의 연결어미와 종결어미 '- 거든'의 사용과 이에 대한 한국어 모어화자의 반응 연구. 이 화여자대학교 석사학위논문.

남현민(2020). 한국어 발화 속도의 지각. 고려대학교 석사학위논 문.

람계서 (2018). 중국인 한국어 학습자들을 위한 한국어 억양연구. '- 다면서, - 르 걸, - 거든, - 르텐데'를 결합한 문장을 중심으로 서울대학교 석사학위논문.

박기영 (2009). 한국어 학습자를 위한 한국어 종결어미의 억양 교 육 방안: 특히 양태 의미에 따른 억양차이를 중심으로. 우리어
문연구, 34, 373-397.

박지연 (2016). 부담 줄이기 기능의 종결어미 '-는데'와 ‘-거든'에 얹히는 문말 억양 연구: 중국어권 한국어 학습자들을 대상으 로. 이중언어학, 64, 1-20.

송암 (2016). 한국어 동형다의 종결어미의 억양실현과 인지에 대 한 실험음성학적 연구: 중국어권 중급, 고급 학습자를 대상으 로. 한국외국어대학교 석사학위논문.

양숙영, 김주영 (2019). 한국어 종결어미 ‘-거든'의 억양: 모어화 자와 6 급 학습자의 예. 새한국어교육, 121, 411-442.

오재혁(2011). 국어 종결 억양의 문법적 기능과 음성적 특징에 대 한 지각적 연구. 고려대학교 박사학위논문.

이지은 (2020). 한국어 종결어미 억양교육 연구. 부산대학교 박사 학위논문.

장주연 (2012). 한국어 동형다의 종결어미의 억양 패턴에 대한 실 
험음성학적 연구. 한국외국어대학교 석사학위논문.

제갈명, 김선정 (2010). 화용론적 기능 중심의 억양교육을 위한 기 초 연구: 중국인 학습자의 한국어 억양분석. 교육문화연구, 16(2), 191-215.

조민하 (2011). 연결어미의 종결기능과 억양의 역할. 고려대학교 박사학위논문.

조민하 (2014). 종결어미 '-거든'의 화용전략과 억양의 기능: 10 대, 20대, 30대의 연령변인을 중심으로. 한국어학, 65, 237-262. 최주희 (2010). 한국어 교육을 위한 화용적 기능의 종결어미 억앙 분석 연구-중국인 고급학습자를 대상으로. 경희대학교 석사 학위논문.

현호정(2013). 중국인 학습자의 한국어 종결기능 연결어미 억앙 에 대한 실험음성학적 연구. 중국인 고급 학습자를 대상으로 한양대학교 석사위논문. 